\title{
Pengaruh Senam Diabetes Terhadap Kadar Gula Darah Pada Pasien Diabetes Mellitus Tipe II Di Wilayah Puskesmas Kedungwuni II Kabupaten Pekalongan
}

\author{
Witri Hastuti ${ }^{1}$, Son Haji ${ }^{2}$, Yusuf Abdillah ${ }^{3}$ \\ 1. STIKes Karya Husada Semarang \\ 2. STIKes Karya Husada Semarang \\ 3. STIKes Karya Husada Semarang \\ E-mail:_witri@stikesyahoedsmg.ac.id
}

\begin{abstract}
Abstrak
Latar belakang: Diabetes mellitus merupakan kelompok penyakit kronis. Diabetes mellitus biasanya disebut sillent killer. Diabetes mellitus merupakan penyakit menahun sehingga mmbutuhkan dalam pengelolaan, seperti olah raga. Olah raga dapat mempengaruhi kadar gula darah sampai 48 jam sesudah seseorang melakukannya. Jumlah pasien diabetes mellitus di Kabupaten Pekalongan Tahun 2015 terdiri dari tipe I sebanyak 171 orang dan tipe II sebanyak 2.393 orang. Tujuan penelitian: untuk mengetahui pengaruh senam diabetes terhadap kadar gula darah pada pasien diabetes mellitus tipe II di Wilayah Puskesmas Kedungwuni II Kabupaten Pekalongan. Metode : desain penelitian menggunakan quasi experiment dengan pendekatan one group pretest posttest. Sampel penelitian adalah pasien diabetes tipe II di wilayah Puskesmas Kedungwuni II Kabupaten Pekalongan sebanyak 38 orang. Pengambilan sampel menggunakan purposive sampling. Instrumen penelitian adalah Glukosameter, Lembar observasi, Standar Operasional Prosedur (SOP). Hasil penelitian: analisis bivariat menggunakan Paried T Test. Hasil penelitian menunjukkan value sebesar $0,000<0,05$. Kesimpulan : Ada pengaruh senam diabetes terhadap kadar gula darah pada pasien diabetes mellitus tipe II di Wilayah Puskesmas Kedungwuni II Kabupaten Pekalongan. Saran : Perawat disarankan untuk menyelenggarakan olah raga dengan durasi waktu yang dilakukan dan prosedur pelaksanaan yang harus dipatuhi oleh diabetesi sebelum dan sesudah melaksanakan senam diabetes mellitus.
\end{abstract}

\section{Kata Kunci: Diabetes Mellitus Tipe II; Kadar Gula; Senam Diabetes}

\section{The Effect Diabetes Gymnastics Against To Blood Sugar Levels In Diabetes Mellitus Type II Patient, Kedungwuni II Public Health Center Pekalongan Regency}

\begin{abstract}
Background: Diabetes mellitus is a chronic disease groups. Diabetes mellitus is usually called sillent killer. Diabetes mellitus is a chronic disease that requires management, such as exercise. Exercise affect blood sugar levels up to 48 hours after someone did it. The number of diabetes mellitus patients at Pekalongan Regency 2015 as many as 171 peoples of type I and type II as many as 2,393 people. Objective: The study aimed determine the effect gymnastics against diabetes to blood sugar levels in patients of diabetes mellitus type II, Kedungwuni II Public Health Center Pekalongan Regency. Methods: The study design used quasi-experimental with one group pretest posttest approach. Samples were diabetes mellitus type II patients in Kedungwuni II Public Health Center Pekalongan Regency as many as 38 peoples. Sampling used purposive sampling. The research instrument were Glukosameter, observation sheets, Standard Operating Procedures (SOP). Result: The result of bivariate analysis by paried $t$ test showed that $\rho$ value $0,000<0.05$. Conclusion: There was the effect gymnastics against diabetes to blood sugar levels in patients of diabetes mellitus type II, Kedungwuni II Public Health Center Pekalongan Regency. Suggestion: Nurses shoud give advise to organize exercies with a duration time and implementation procedures to be followed by diabetics before and after do gymnastic diabetes mellitus.
\end{abstract}

Keywords: Diabetes Mellitus Type II; Blood Sugar Level; Gymnastics Diabetes

Jurnal SMART Keperawatan Sekolah Tinggi Ilmu Kesehatan (STIKes) Karya Husada Semarang

www.stikesyahoedsmg.ac.id/ojs/index.php/sjkp(perawat) 


\section{Pendahuluan}

Diabetes mellitus merupakan penyakit kelompok penyakit kronis yang mengacu pada penyakit dengan kadar gula darah yang tinggi yang disebabkan tubuh tidak lagi memiliki hormon insulin atau insulin tidak dapat bekerja sebagaimana mestinya. Diabetes mellitus biasanya disebut sillent killer yang membunuh diam-diam atau menyerang secara diamdiam (Waluyo, 2009).

Olah raga dapat mempengaruhi kadar gula darah sampai 48 jam sesudah seseorang melakukannya. Pada saat olah raga, tubuh akan menarik simpanan glikogen yang ada dalam hati dan otot yang dikeluarkan untuk menyediakan energi. Biasanya setelah 20-30 menit berolah raga, simpanan energi akan habis dan jika terlalu memaksakan diri kadar glukosa darah akan naik kembali (D’Adamo \& Whitney, 2007).

Prinsip mengontrol kadar gula darah dengan olah raga dapat dilakukan pada pasien diabetes mellitus tipe I dan tipe II. Olah raga tidak boleh dilakukan pada pasien diabetes mellitus dengan kadar glukosa darah yang tak terkontrol $(<70 \mathrm{mg} \%$ atau $>250 \mathrm{mg} \%)$ atau bila terdapat keton bodies dalam urine karena bahaya ketoasidosis (Hartono, 2006). Prinsip olah raga bagi penderita diabetes mellitus adalah kontinyu artinya olah raga yang dilakukan terus menerus tanpa henti selama 30 menit dan memiliki ritme yang teratur seperti joging, senam, bersepeda dan jalan kaki (Nurjanah \& Jualianti, 2007). Khusus untuk penderita diabetes mellitus tipe I dan II dianjurkan untuk melakukan senam diabetes (Vitahealth, 2008). Bagi penderita diabetes mellitus (diabetesi) olah raga seperti senam secara teratur berfungsi untuk membantu menormalkan kadar gula darah sehingga mengurangi kebutuhan terhadap obat-obatan atau insulin (AgroMedia, 2009). Hasil penelitian Rahmawati (2010) menyebutkan bahwa latihan jasmani pada penderita diabetes mellitus tipe II dapat menurunkan glukosa darah.

Berdasarkan Data Dinas Kesehatan Kabupaten Pekalongan dapat diketahui jumlah pasien diabetes mellitus tipe I tahun 2015 sebanyak 171 orang dan pasien diabetes mellitus tipe II sebanyak 2.393 orang. Puskesmas Kedungwuni II merupakan salah satu puskesmas yang mempunyai penderita diabetes mellitus tipe II cukup banyak di Kabupaten Pekalongan yaitu pada tahun 2014 sebanyak 124 orang, tahun 2015 sebanyak 119 orang dan Januari-Juni 2016 sebanyak 72 orang. Dari studi pendahuluan terhadap pengelola Program Penyakit Tidak Menular (PTM) Puskesmas Kedungwuni II diketahui bahwa di wilayah kerja Puskesmas 
Kedungwuni II belum ada kelompok senam diabetes. Penelitian ini bertujuan untuk mengetahui pengaruh senam diabetes terhadap kadar gula darah pada pasien diabetes mellitus tipe II di Wilayah Puskesmas Kedungwuni II Kabupaten Pekalongan.

\section{Tinjauan Teoritis}

Diabetes mellitus adalah hiperglikemia yang disebabkan karena kurangnya pembentukan insulin atau resistensi jaringan perifer terhadap insulin (Graber dkk, 2006) Pencegahan primer adalah pencegahan terjadinya diabetes mellitus pada individu yang beresiko untuk mendapatkan diabetes seperti halnya yang memiliki garis keluarga yang menderita diabetes atau mereka yang pola hidupnya cenderung beresiko tinggi. (Iskandar, 2010).

Pencegahan sekunder merupakan tindakan pencegahan terjadinya komplikasi akut maupun komplikasi jangka panjang. Pemeriksaan mata secara rutin dan pengobatan retinopati, mencegah protein dalam urine untuk menghindari terjadinya gagal ginjal. Oleh karena itu, masyarakat kita harus lebih waspada serta peduli terhadap penyakit diabetes dengan cara mengubah gaya hidup, pola makan serta rajin berolah raga (Iskandar, 2010).

Gula darah atau glukosa darah adalah salah satu karbohidrat terpenting yang digunakan sebagai sumber tenaga. Glukosa adalah monosakarida berkarbon enam (heksosa) yang digunakan sebagai sumber dasar energi oleh kebanyakan sel heterotrofik (Stanfield, 2006)

Gula dalam darah yang masuk melalui mulut dan dicernakan di usus kemudian diserap ke dalam aliran darah. Glukosa merupakan sumber energi utama bagi sel tubuh di otot dan jaringan. hasil pemeriksaan kadar glukosa darah puasanya < 100 mg/DL, kadar glukosa darah 1 jam setelah meminum larutan glukosa $<180 \mathrm{mg} / \mathrm{DL}$, dan hasil pemeriksaan kadar glukosa darah 2 jam setelah minum larutan glukosa $<140$ mg/DL (Mahendra, dkk 2010). Senam diabetes mellitus adalah senam aerobic low impact dan ritmis gerakan menyenangkan tidak membosankan dan dapat diikuti semua kelompok umur sehingga menarik antusiasme kelompok senam dalam klub-klub diabetes (Santoso, 2008).

\section{Metode Penelitian}

Desain dalam penelitian ini menggunakan quasi experiment yaitu suatu rancangan yang bertujuan mengungkapkan hubungan sebab akibat dengan cara melibatkan kelompok kontrol di samping kelompok eksperimental tetapi pemilihan kelompok tidak menggunakan teknik acak. Pendekatan yang digunakan yaitu one group pretest posttest. Penelitian dilakukan di Wilayah 
Puskesmas Kedungwuni II pada Bulan Desember 2016. Populasi dalam penelitian ini adalah semua pasien diabetes tipe II di wilayah Puskesmas Kedungwuni II Kabupaten Pekalongan bulan Januari-Juni 2016 sebanyak 72 orang. Sampel penelitian menjadi 19 orang. Teknik pengambilan sampel purposive sampling. Analisa univariat dalam penelitian ini menghasilkan nilai tendensi central kadar gula darah sebelum dan sesudah diberikan intervensi berupa mean, median, modus. Analisa bivariate yang dilakukan terhadap dua variabel yang diduga berhubungan atau berkorelasi (Notoatmodjo, 2012). Hasil uji normalitas diperoleh distribusi data normal maka uji statistik menggunakan Paired T Test .

\section{Hasil Penelitian}

Kadar Gula Darah pada Pasien Diabetes Mellitus Tipe II Sebelum Diberikan Senam Diabetes

Tabel 1 Distribusi Nilai Gula Darah pada Responden Sebelum Diberikan Senam Diabetes Mellitus di Wilayah Puskesmas Kedungwuni II KabupatenPekalongan

\begin{tabular}{|c|c|c|c|c|c|c|}
\hline Variabel & $\mathrm{N}$ & Mean & Median & Min & Max & Sig \\
\hline $\begin{array}{l}\text { Kadar gula darah } \\
\text { (sebelum test) }\end{array}$ & 19 & 210,42 & 207 & 180 & 268 & 0,102 \\
\hline
\end{tabular}

Tabel 1 menunjukkan bahwa rata-rata kadar gula darah responden sebesar 210,42 gr dl, kadar gula darah terendah 180 gr dl dan tertinggi 268 gr dl. Hasil uji normalitas shapiro wilk kadar gula darah sebelum diberikan senam diabetes mellitus diperoleh sig sebesar 0,102>0,05 sehingga distribusi data dikatakan normal.

Kadar Gula Darah pada Pasien Diabetes Mellitus Tipe II Sesudah Diberikan Senam Diabetes

Tabel 2 Distribusi Nilai Gula Darah pada Responden Sesudah Diberikan Senam Diabetes Mellitus di Wilayah Puskesmas Kedungwuni II Kota Pekalongan

\begin{tabular}{lcccccc}
\hline \multicolumn{1}{c}{ Variabel } & N & Mean & Median & Min & Max & Sig \\
\hline $\begin{array}{l}\text { Kadar gula darah } \\
\text { (sesudah test) }\end{array}$ & $\mathbf{1 9}$ & $\mathbf{1 8 1 , 0 7}$ & $\mathbf{1 7 8 , 8}$ & $\mathbf{1 6 7}$ & $\mathbf{2 0 7}$ & $\mathbf{0 , 1 5 5}$ \\
\hline
\end{tabular}

Tabel 2 menunjukkan bahwa rata-rata kadar gula darah responden sebesar 181,07 gr dl, kadar gula darah terendah 167 gr dl dan tertinggi 207 gr dl. Hasil uji normalitas shapiro wilk kadar gula darah sebelum diberikan senam diabetes mellitus diperoleh sig sebesar 0,155>0,05 sehingga distribusi data dikatakan normal. 
Pengaruh Senam Diabetes Terhadap Kadar Gula Darah pada Pasien Diabetes Mellitus Tipe II

Analisa bivariat menggunakan uji statistik Paired $T$ test karena hasil kadar gula darah sebelum dan sesudah senam diabetes mellitus berdistribusi normal. Hasil penelitian diuraikan sebagai berikut :

Tabel 3 Pengaruh Senam Diabetes Terhadap Kadar Gula Darah Pada Pasien Diabetes Mellitus Tipe II di Wilayah Puskesmas Kedungwuni II Kabupaten Pekalongan

\begin{tabular}{lcccc}
\hline & N & Mean & SD & p value \\
\hline $\begin{array}{l}\text { Nilai gula darah } \\
\text { (sebelum test) }\end{array}$ & 19 & 210,42 & 20,573 & \\
$\begin{array}{l}\text { Nilai gula darah } \\
\text { (sesudah test) }\end{array}$ & 19 & 181,07 & 9,269 & \\
\hline
\end{tabular}

Hasil uji paired T tets diperoleh $\rho$ value sebesar $0,000<0,05$, yang berarti ada pengaruh senam diabetes terhadap kadar gula darah pada pasien diabetes mellitus tipe II di Wilayah Puskesmas Kedungwuni II Kabupaten Pekalongan.

\section{Pembahasan}

\section{Kadar Gula Darah pada Pasien Diabetes Mellitus Tipe II Sebelum Diberikan Senam Diabetes}

Hasil penelitian menunjukkan bahwa menunjukkan bahwa rata-rata kadar gula darah responden sebesar 210,42 gr dl, kadar gula darah terendah 180 gr dl dan tertinggi 268 gr dl. Dari hasil tersebut dapat disimpulkan bahwa kadar gula darah responden di atas batas normal yaitu $180 \mathrm{mg} \mathrm{dl}$.

Pasien diabetes mellitus mempunyai kadar gula darah yang tinggi diakibatkan gangguan sensitivitas sel $\beta$ pankreas untuk menghasilkan hormon insulin yang berperan sebagai pengontrol kadar gula darah dalam tubuh. Hal ini sesuai dengan pendapat Mistra (2008) yang menyatakan bahwa salah satu penyebab diabetes mellitus adalah kerusakan kelenjar pankreas (tidak lagi memproduksi hormon insulin atau sedikit memproduksi hormon tersebut). 
Pasien diabetes mellitus tipe II dengan kadar gula di atas $180 \mathrm{mg}$ dl membutuhkan pengelolaan yang baik untuk mencegah terjadinya komplikasi yang diakibatkan oleh peningkatan kadar gula darah. Hasil penelitian Sinaga (2011) menyebutkan bahwa jenis komplikasi pasien yang menjalani rawat inap di RS Vita Insani Pematang Siantar meliputi ulcus-gangren $(26,1 \%)$ dan komplikasi kronik $(85,1 \%)$

\section{Kadar Gula Darah pada Pasien Diabetes Mellitus Tipe II Sesudah Diberikan Senam Diabetes}

Hasil penelitian menunjukkan bahwa rata-rata kadar gula darah responden sebesar 181,07 gr dl, kadar gula darah terendah 167 gr dl dan tertinggi 207 gr dl. Dari hasil tersebut dapat disimpulkan bahwa responden setelah mengikuti senam diabetes mellitus secara teratur mengalami penurunan kadar gula darah secara signifikan. Hal ini dapat dilihat dari nilai rata-rata mengalami penurunan dari $210,42 \mathrm{gr}$ dl sebelum diberikan senam diabetes mellitus menjadi 181,07 sesudah diberikan senam diabetes mellitus.

Penurunan kadar gula darah setelah senam diabetes mellitus disebabkan tubuh selama menjalani senam diabetes mellitus membakar kalori dalam tubuh dan memperbaiki sirkulasi darah sehingga dapat meningkatkan jumlah reseptor pada dinding sel tempat insulin diproduksi. Hal ini sesuai dengan Misnadiarly (2008) yang menyatakan bahwa membantu membakar kalori karena dapat mengurangi berat badan, meningkatkan jumlah reseptor pada dinding sel tempat insulin bisa melekatkan diri, memperbaiki sirkulasi darah dan menguatkan otot jantung, meningkatkan kadar kolesterol baik dan mengurangi kolesterol jahat dan membantu melepaskan kecemasan, stres, dan ketegangan sehingga memberikan rasa sehat dan bugar.

Dalimartha (2012) menyatakan bahwa penderita diabetes mellitus tipe 2 dapat melakukan pengelolaan dengan olahraga (latihan jasmani) karena dapat menuurnkan kadar glukosa darah. Hasil penelitian Nurhidayah (2013) menyebutkan bahwa ada pengaruh senam diabetes terhadap penurunan kadar gula darah pada lansia.

\section{Pengaruh Senam Diabetes Terhadap Kadar Gula Darah Pasien Diabetes Mellitus Tipe II}

Hasil uji paired T tets diperoleh $\rho$ value sebesar $0,000<0,05$, yang berarti ada pengaruh senam diabetes terhadap kadar gula darah pada pasien diabetes mellitus tipe II di Wilayah Puskesmas Kedungwuni II Kabupaten Pekalongan. Senam diabetes mellitus yang dilakukan dapat menurunkan kadar gula darah pasien diabetes mellitus tipe II. Olah raga senam 
diabetes mellitus pada pasien diabetes mellitus tipe II dapat mengurangi penggunaan obatobatan dan insulin. Hal ini sesuai dengan AgroMedia (2009) yang menyatakan bahwa bagi penderita diabetes mellitus (diabetesi) olah raga seperti senam secara teratur berfungsi untuk membantu menormalkan kadar gula darah sehingga mengurangi kebutuhan terhadap obat-obatan atau insulin.

Senam diabetes mellitus pada pasien diabetes mellitus tipe II dapat menurunkan kadar gula darah, namun pelaksanaannya harus dilakukan secara kontinu. Hasil penelitian ini sesuai dengan penelitian Nurhidayah (2013) yang menyatakan bahwa ada pengaruh senam diabetes terhadap penurunan kadar gula darah pada lansia di Perwira Sari RW 08 Bekasi Utara.

\section{Kesimpulan}

Karakteristik responden menunjukkan bahwa 47,4\% responden berumur 44-48 tahun, 68,4\% responden berjenis kelamin laki-laki, 47,4\% responden masing-masing berpendidikan dasar dan menengah dan $42,1 \%$ responden masing-masing bekerja sebagai pedagang dan tidak bekerja. Nilai rata-rata kadar gula darah pada pasien sebelum senam diabetes mellitus sebesar 210,42 gr dl, kadar gula darah terendah 180 gr dl dan tertinggi 268 gr dl. Nilai rata-rata kadar gula darah pada pasien sesudah senam diabetes mellitus sebesar 181,07 gr dl, kadar gula darah terendah $167 \mathrm{gr}$ dl dan tertinggi $207 \mathrm{gr}$ dl. Ada pengaruh senam diabetes terhadap kadar gula darah pada pasien diabetes mellitus tipe II di Wilayah Puskesmas Kedungwuni II Kabupaten Pekalongan dengan $\rho$ value $0,000<0,05$

\section{Saran}

Pasien diabetes mellitus perlu meningkatkan aktivitas senam diabetes mellitus secara teratur dan rutin untuk mengontrol kadar glukosa darah. Hasil penelitian ini diharapkan dapat dijadikan sebagai sumber informasi oleh profesi keperawatan bahwa senam diabetes mellitus secara teratur efektif untuk mengontrol kadar glukosa darah. Efektivitas pelaksanaan olah raga tergantung pada durasi waktu yang dilakukan dan prosedur pelaksanaan yang harus dipatuhi oleh diabetesi sebelum dan sesudah melaksanakan senam diabetes mellitus

\section{Daftar Pustaka}

1. Waluyo. (2009). 100 Questions \& Answer. Diabetes. Jakarta: PT. Elex Media 
Komputindo.

2. WHO, 2015, Diabetes, http://www.who.int, diunduh diperoleh tanggal 15 Juni 2016

3. D’Adamo \& Whitney. (2007). Diabetes: Memerangi Diabetes Melalui Diet Golongan Darah dan Pola Makan yang Benar. Yogyakarta: B-First.

4. Rahmawati. (2010). Hubungan Latihan Jasmani Terhadap Kadar Glukosa Darah Penderita Diabetes Mellitus Tipe II. Surakarta: Universitas Negeri Sebelas Maret

5. Vitahealth. (2008). Diabetes: Informasi untuk Penderita dan Keluarganya. Jakarta: PT. Gramedia Pustaka Utama.

6. Iskandar. (2010). Health Triad (Body. Mind. and System) Sehat. Antusias. Energik Melalui Sinkronisasi Tubuh. Pikiran dan Sistem Health Triad (Tiga Serangkai Kesehatan). Jakarta: PT. Elex Media Komputindo.

7. Santoso. (2008). Senam Diabetes. Jakarta: Persadia.

8. Stanfield. (2006). Biologi Molekuler dan Sel. Jakarta: Erlangga.

9. Mahendra dkk. (2008). Care Your Self Diabetes Mellitus. Depok: Penebar Plus

10. Nurhidayah (2013). Pengaruh Senam Diabetes Terhadap Penurunan Kadar Gula Darah pada Lansia di Perwira Sari RW 08 Bekasi Utara. Jakarta: STIKES Yarsi 